\title{
DETERMINATION OF NONSPECIFIC LIPID TRANSFER PROTEIN IN RAT TISSUES AND MORRIS HEPATOMAS BY ENZYME IMMUNOASSAY
}

\author{
TOM TEERLINK, THEO P. VAN DEK KRIFI, G. PAUL H. VAN HEUSDEN and KAREL W,A. WIRI"L \\ Laboratory of Biochemistry, State University of Utrecht, University Centre De Uithof, Transitorium 3, Padualaan 8, NL-3584 CH Utrecht \\ (The Netherlands)
}

(Received July 7th, 1983)

(Revised manuscript received November 30th, 1983)

Key words: Lipid transfer protein; Enzyme immunoassay; Diacylphospholipid; Cholesterol; (Rat)

Rat tissues contain a nonspecific transfer protein which in vitro mediates the transfer of diacylphospholipids as well as cholesterol between membranes. This protein appears identical to sterol carrier protein ${ }_{2}$. A specific enzyme immunoassay for this protein was developed using antibodies raised in rabbits, against a homogeneous protein from rat liver. This assay was based on the very high affinity of the nonspecific lipid transfer protein for polyvinyl surfaces. A reproducible adsorption was achieved by presenting the protein to the surface in the presence of a large excess of bovine serum albumin. The adsorbed protein was detected with specific immunoglobulin (IgG) isolated by antigen-linked affinity chromatography and a goat anti-rabbit IgG-enzyme conjugate. Adsorption was proportional to the amount of protein present, giving rise to a linear standard curve. The enzyme immunoassay measured transfer protein levels in the range 0.2-2 ng. The highest concentrations of transfer protein were found in liver and intestinal mucosa. Levels in other tissues including brain, lung, kidney, spleen, heart, adrenals, ovary and testis were 5-10-fold lower than in liver. In the fast-growing Morris hepatoma 7777 the concentration of nonspecific lipid transfer protein was approximately one-tenth of that measured in the host liver, whereas a reduction of $65 \%$ was observed in the slow-growing Morris hepatomas 7787 and 9633 . Subcellular distribution studies showed that approx. $70 \%$ of the transfer protein was present in the soluble supernatant fraction.

\section{Introduction}

Rat liver cytosol contains a nonspecific lipid transfer protein which facilitates the transfer of phosphatidylethanolamine, phosphatidylcholine, phosphatidylinositol, phosphatidylserine, sphingomyelin and cholesterol between membranes [1-3]. This protein appears identical to one of the cytosolic proteins, known to modulate cholesterol biosynthesis, i.e., the sterol carrier protein 2 [4,5]. Inherent to its ability to mediate the transfer of cholesterol to membranes, this protein stimulates the microsomal acyl CoA : cholesterol acyltransferase activity [5-7]. Recently it has also been demonstrated that in vitro the sterol carrier protein $_{2}$ can stimulate pregnenolone synthesis by transferring cholesterol from adrenal lipid droplets to mitochondria [8].

The above studies strongly suggest that the nonspecific lipid transfer protein may play a regulatory role in the intracellular cholesterol metabolism. Recently we have shown by using a specific phospholipid transfer assay that this protein is almost absent from the $105000 \times \mathrm{g}$ supernatant fraction of Morris hepatomas 7777, 7787 and 9633 [9]. This has been confirmed by measuring the cholesterol exchange activity in the cytosol from Morris hepatoma 7777 [5]. As suggested previ- 
ously, this deficiency may be related to the poorly regulated cholesterol biosynthesis in hepatomas [10,11].

In order to determine accurately the levels of the nonspecific lipid transfer protein, we have chosen to develop a quantative immunoassay. Here we report on an enzyme immunoassay for this protein. Data are presented on the levels of this protein in rat tissues and Morris hepatomas and on the subcellular distribution of the protein in liver.

\section{Materials and Methods}

\section{Materials}

Polyvinylchloride microtiter plates were obtained from Flow Laboratories (McLean, VA, U.S.A.); $O$-phenylenediamine from Sigma (St. Louis, MO, U.S.A.); goat anti-rabbit IgG conjugated to horseradish peroxidase from Nordic Immunological Laboratories (Tilburg, The Netherlands); cyanogen bromide from Pierce (Rockford, IL, U.S.A.); AcA-54 from LKB (Bromma, Sweden); Sepharose 4B from Pharmacia (Uppsala, Sweden) and bovine serum albumin from Calbiochem (San Diego, CA, U.S.A.). All other chemicals used were of analytical grade.

\section{Methods}

Purification of phospholipid transfer proteins. The nonspecific lipid transfer protein from rat liver was purified as described [3]. After the last step of purification the material was routinely submitted to molecular sieve chromatography on a column of ultragel AcA-54. This yielded one single protein peak in the low molecular weight region which exactly coincided with the phosphatidylethanolamine transfer activity [3]. The homogeneity of the protein was further established by electrophoresis on SDS-polyacrylamide gels [3]. Proteins were stored in $50 \%$ glycerol at $-20^{\circ} \mathrm{C}$.

Production and detection of antibodies. Nonspecific lipid transfer protein $(0.1 \mathrm{mg})$ obtained after rechromatography on a column of AcA-54 was dialyzed against $0.9 \%(\mathrm{w} / \mathrm{v}) \mathrm{NaCl}$. This solution $(1 \mathrm{ml})$ was added to a test tube coated with a film of egg phosphatidylcholine $(1 \mathrm{mg})$. After vortexing the solution was sonicated for $1 \mathrm{~min}$ in an ice bath. The ensuing antigen suspension was emulsified with an equal volume of Freund's complete adjuvant and injected intradermally in multiple spots on the back of a female New Zealand rabbit. After 4 weeks this immunization procedure was repeated. After another 4 weeks a subcutaneous booster injection was given of $0.1 \mathrm{mg}$ of transfer protein in $0.9 \%(\mathrm{w} / \mathrm{v}) \mathrm{NaCl}$, suspended by sonication with $1 \mathrm{mg}$ of egg phosphatidylcholine. Ten days afterwards the booster blood was collected from the ear veins and serum was prepared. During the following year the animals were boosted at 2-month intervals, which resulted in a gradual increase in titer of the antiserum.

Sera were screened for the production of antibodies by enzyme-linked immunosorbent assay [12].

Purification of the specific immunoglobulin fraction from antiserum. Total $\mathrm{IgG}$ was isolated from the serum as described before [9]. A specific IgG fraction was obtained by affinity chromatography according to the procedure previously described [13]. Briefly, $1 \mathrm{mg}$ of nonspecific lipid transfer protein was coupled to $2 \mathrm{~g}$ (wet weight) cyanogen bromide-activated Sepharose 4B. A small column was packed with this material in phosphatebuffered saline $(0.15 \mathrm{M} \mathrm{NaCl} / 0.01 \mathrm{M}$ sodium phosphate, $\mathrm{pH} 7.2$ ) and approx. $150 \mathrm{mg}$ crude $\operatorname{IgG}$ were applied to the column. The non-bound protein was removed by washing the column with phosphate-buffered saline and the specific $\operatorname{IgG}$ was eluted with $0.15 \mathrm{M} \mathrm{NaCl} / 0.5 \mathrm{M}$ formic acid (pH 2.0). Fractions were neutralized with $1 \mathrm{M}$ Tris- $\mathrm{HCl}$ ( $\mathrm{pH} 8.0$ ), dialyzed overnight against phosphate-buffered saline and stored in aliquots at $-20^{\circ} \mathrm{C}$.

Preparation of samples. Tissue homogenates, subcellular membrane fractions and $105000 \times g$ supernatant fractions were prepared from Wistar rats as described before [14]. Prior to use the rats were fasted overnight. Protein concentrations were determined according to Lowry et al. [15] with bovine serum albumin as standard.

As an essential step in the enzyme immunoassay (see Results) the samples were heated at $90^{\circ} \mathrm{C}$ for $5 \mathrm{~min}$. Coagulated protein was removed by centrifugation for $10 \mathrm{~min}$ at $20000 \times \mathrm{g}$. Prior to heating, the $105000 \times g$ supernatant fractions were diluted with $0.1 \%(\mathrm{w} / \mathrm{v})$ bovine serum albumin in phosphate-buffered saline to a sample protein con- 
centration of less than $1 \mathrm{mg} / \mathrm{ml}$. The admixture with bovine serum albumin prevented the loss of nonspecific lipid transfer protein by aspecific coprecipitation. Homogenates and subcellular membrane fractions were treated in a similar way, except that sodium deoxycholate was added to a final concentration of $0.05 \%(\mathrm{w} / \mathrm{v})$ to ensure a complete release of membrane-bound transfer protein.

Enzyme immunoassay procedure. The heattreated samples were further diluted with $0.1 \%$ $(w / v)$ bovine serum albumin in phosphatebuffered saline so that measurable levels of transfer protein were attained. Depending on the amount of transfer protein present the dilution resulted in a 15-500-fold excess of serum albumin over sample protein. Standard curves were prepared of nonspecific lipid transfer protein diluted in the same albumin-containing phosphate buffer. In the instance where samples contained $0.05 \%$ (w/v) deoxycholate care was taken that this detergent concentration was maintained upon further dilution. Samples for the standard curve also contained $0.05 \%(\mathrm{w} / \mathrm{v})$ deoxycholate. The samples $(0.1 \mathrm{ml})$ were pipetted into the wells of a microtiter plate and this plate was incubated in a humid atmosphere for $1 \mathrm{~h}$ at $37^{\circ} \mathrm{C}$. Then the plate was washed six times with phosphate-buffered saline, containing $0.05 \%(\mathrm{w} / \mathrm{v})$ l'ween-20 (buffer $\mathrm{A}$ ). Washing involved pouring the buffer on the plate followed by flicking it off. Then all wells werc incubated with $0.1 \mathrm{ml}$ of buffer $\mathrm{A}$, containing specific $\operatorname{IgG}$ at the desired concentration and $1 \%$ $(w / v)$ bovine serum albumin. Incubation was performed for $1 \mathrm{~h}$ at room temperature. The plate was washed six times with buffer $A$ and then all wells received $0.1 \mathrm{ml}$ of a solution of goat anti-rabbit IgG conjugated with horseradish peroxidase diluted $1: 1000$ in buffer A containing $1 \%(\mathrm{w} / \mathrm{v})$ bovine serum albumin. After $1 \mathrm{~h}$ incubation at room temperature the plate was washed six times with buffer $A$ and $0.1 \mathrm{ml}$ of substrate solution was added to each well. The substrate solution contained $0.04 \%(\mathrm{w} / \mathrm{v}) \quad O$-phenylenediamine and $0.012 \%(\mathrm{w} / \mathrm{v}) \mathrm{H}_{2} \mathrm{O}_{2}$ in $0.05 \mathrm{M}$ phosphate $/ 0.025 \mathrm{M}$ citrate buffer ( $\mathrm{pH} 5.0$ ). Incubation was performed for $30 \mathrm{~min}$ at room temperature in the dark. Then an aliquot $(0.08 \mathrm{ml})$ was drawn from each well and mixed with $1 \mathrm{ml}$ of $1 \mathrm{M} \mathrm{H}_{2} \mathrm{SO}_{4}$ to stop the reaction. Absorbance was read at $492 \mathrm{~nm}$. The standard curves were based on six dilutions of pure nonspecific lipid transfer protein measured in quadruplicate. In the assay, six dilutions of the samples were used, measured in duplicate.

Hepatomas. Morris hepatomas 7777,7787 and 9633 were maintained in Buffalo-strain rats and used for the preparation of the $105000 \times g$ supernatant fraction as described before [9].

Transfer assay. Activity of the nonspecific lipid transfer protein was determined by measuring the transfer of $\left[{ }^{14} \mathrm{C}\right.$ phosphatidylethanolamine from vesicles to bovine heart mitochondria as previously described $[9,16]$.

\section{Results}

\section{Production of antisera}

Immunization of rabbits with the nonspecific lipid transfer protein admixed with Freund's complete adjuvant did not result in an antiserum. Attempts to increase the immunogenicity of the transfer protein by self-polymerization with glutaraldehyde or covalent attachment to either bovine serum albumin or thyroglobulin were unsuccessful as well. We finally succeeded in raising an antiserum by immunization with a sonicated suspension of transfer protein and egg phosphatidylcholine. Recently, an antiserum against a sphingomyelin transfer protein has been raised in a similar manner [17].

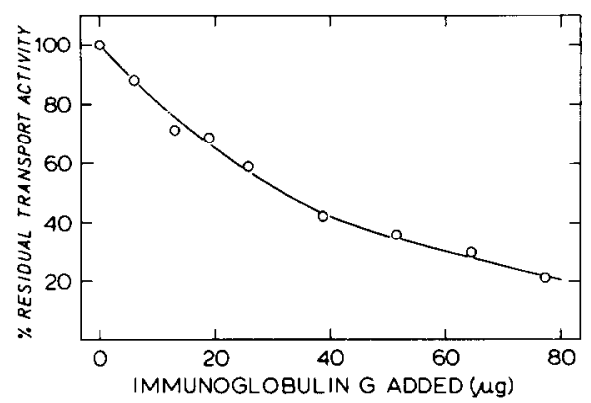

Fig. 1. Inhibition of phosphatidylethanolamine transfer activity by specific anti-nonspecific lipid transfer protein IgG. Purified nonspecific lipid transfer protein $(1.9 \mu \mathrm{g})$ was incubated in 0.4 $\mathrm{ml}$ of $0.25 \mathrm{M}$ sucrose $/ 5 \mathrm{mM}$ Tris-HCl $/ 2 \mathrm{mM}$ EDTA (pH 7.4) with the indicated amounts of specific anti-nonspecific lipid transfer protein $\mathrm{IgG}$ in the presence of $2 \mathrm{mg}$ of bovine serum albumin for $3 n \mathrm{~min}$ at $37^{\circ} \mathrm{C}$. The mixture was cooled to $0^{\circ} \mathrm{C}$ and after $1 \mathrm{~h}$ the phosphatidylethanolamine transfer activity was determined. 
Screening of the antisera by enzyme-linked immunosorbent assay indicated that the titer was very low. Hence, we routinely used in this study specific IgG isolated by antigen-linked affinity chromatography. By this technique we could estimate that $1-2 \%$ of the total IgG consisted of the specific antibody.

The functional activity of the nonspecific lipid transfer protein is routinely assayed by measuring its ability to transfer phosphatidylethanolamine between membranes (see Materials and Methods). Titration of a fixed amount of transfer protein (1.9 $\mu \mathrm{g})$ with specific IgG progressively inhibited this transferring activity, indicating that antibodies were raised against the proper antigen (Fig. 1).

Titration with total IgG (up to $0.3 \mathrm{mg}$ of protein) did not give any detectable inhibition of transfer activity, confirming the very low titer of the antiserum (see above). The amount of total IgG had to be raised to $0.8 \mathrm{mg}$ of protein to observe an inhibition of $20 \%$. The formation of the antigen-antibody complex was also investigated by Ouchterlony double diffusion experiments using pure nonspecific lipid transfer protein and specific IgG. However, visible precipitation lines were not observed.

\section{Properties of antigen and antibody}

The nonspecific lipid transfer protein lost its immunoreactivity upon labeling with iodine-125 using either $\mathrm{H}_{2} \mathrm{O}_{2}$-lactoperoxidase or BoltonHunter reagent. This precluded the development of a regular radioimmunoassay. We have also attempted to develop a 'sandwich' assay, where the antigen was bound to immobilized IgG and quantified by reaction with excess ${ }^{125}$ I-labeled specific IgG [19]. In our hands, binding of the labeled IgG was not observed, suggesting that the nonspecific lipid transfer protein has one antigenic site. This would be in agreement with the observation that double diffusion did not give precipitation lines (see above). To circumvent this limitation we have set up a competitive immunosorbent assay, where immobilized and free antigen compete for a limited amount of specific IgG [12]. Initial experiments, however, showed that this kind of assay was not sensitive enough, probably because of a low affinity of the IgG molecule. Our experiences, gained by investigating the adsorption of the nonspecific lipid transfer protein to plastic surfaces, formed the basis for a new kind of enzyme immunoassay used in the present study.

\section{Enzyme immunoassay}

Pure transfer protein or a sample is applied to the well of a microtiter plate in the presence of excess bovine serum albumin. Adsorbed transfer protein is determined by incubation with specific IgG, followed by peroxidase-linked second antibody. The amount adsorbed was found to be proportional to the concentration in the sample. This is exemplified in Fig. 2, which shows a set of standard curves at different IgG concentrations. At each IgG concentration these curves were linear up to an absorbance of 1.0. It can be estimated that at the lowest $\operatorname{IgG}$ concentration $(0.25 \mu \mathrm{g}$. $\mathrm{ml}^{-1}$ ) the number of $\mathrm{IgG}$ molecules exceeds that of the transfer protein molecules adsorbed. Despite this excess, the assay becomes more sensitive with increasing amounts of $\operatorname{IgG}$ (Fig. 2). This is probably due to the low affinity of the $\mathrm{IgG}$ used resulting in a slow formation of the IgG transfer protein complex during the $1 \mathrm{~h}$ of incubation. An increase of the $\mathrm{IgG}$ concentration will shift the equilibrium towards formation of the complex, thereby enhancing the response of the assay. Incubations overnight abolished these differences. This assay displayed an optimal reproducibility

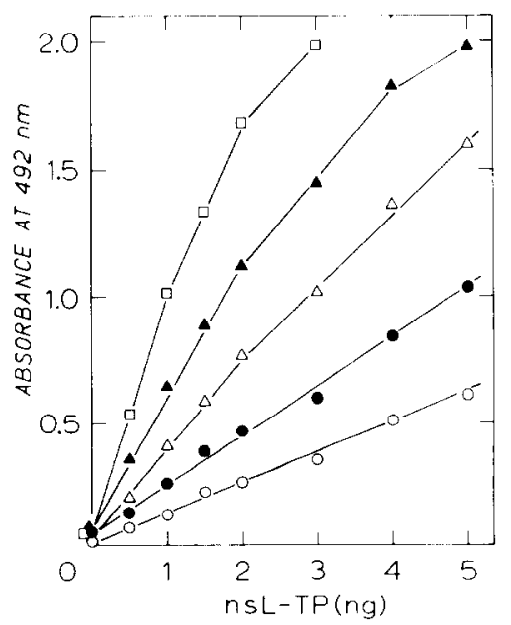

Fig. 2. Enzyme immunoassay standard curves for nonspecific lipid transfer protein at different IgG concentrations. The following concentrations of specific IgG were used: $0.25 \mu \mathrm{g}$. $\mathrm{ml}^{-1}(\mathrm{O}), 0.50 \mu \mathrm{g} \cdot \mathrm{ml}^{-1}(\bullet), 1.00 \mu \mathrm{g} \cdot \mathrm{ml}^{-1}(\Delta), 2.0 \mu \mathrm{g} \cdot \mathrm{ml}^{-1}$ (৫) and $4.0 \mu \mathrm{g} \cdot \mathrm{ml}^{-1}$ (口). 
and sensitivity by using specific anti-nonspecific lipid transfer protein IgG. When comparable amounts of total IgG both from immunized and non-immunized rabbits were used in the assay, no response was observed. The antibody used has been raised against a sonicated dispersion of transfer protein and phosphatidylcholine. However, sonicated phosphatidylcholine without transfer protein gave no response in the assay.

The nonspecific lipid transfer protein can be determined by the kind of enzyme immunoassay described, because of its ability to adsorb to a plastic surface in the presence of a large excess of serum albumin. In order to determine what percentage of the transfer protein is adsorbed during the coating step, the following experiment was performed. Wells were coated with a $0.1 \%(\mathrm{w} / \mathrm{v})$ albumin solution containing $0.5,1$ and 2 ng transfer protein. After the first coating, the solutions were recovered and used to coat a second plate. Both plates were then incubated with specific $\mathrm{IgG}$, second antibody and substrate to determine the amount of transfer protein adsorbed. Independent of the initial antigen concentration, the amount of transfer protein on the second plate was $33 \pm 2 \%$ less than on the first plate. This percentage reflects the adsorption of the transfer protein to the well. The coating buffer contained $0.05 \%(\mathrm{w} / \mathrm{v})$ sodium deoxycholate when transfer protein was determined in samples of total homogenate or subcellular membrane fractions (see Materials and Methods). Under these conditions we observed that the amount of transfer protein on the second plate was $52 \pm 4 \%$ less than on the first plate. This indicates that the adsorption of transfer protein to the well is enhanced by sodium deoxycholate. Hence, the color yield at $492 \mathrm{~nm}$ for the standard curves is increased in the presence of $0.05 \%(\mathrm{w} / \mathrm{v})$ sodium deoxycholate (cf. Fig. 2). A similar enhancement of color yield was observed for the $105000 \times g$ supernatant fraction from rat liver. However, in reference to this standard curve, the amount of transfer protein determined was not affected by the sodium deoxycholate.

To test the specificity of the enzyme immunoassay a $105000 \times g$ supernatant from rat liver was fractionated by molecular sieve chromatography on a column of AcA-54. Fractions were both assayed for phosphatidylethanolamine transfer ac-

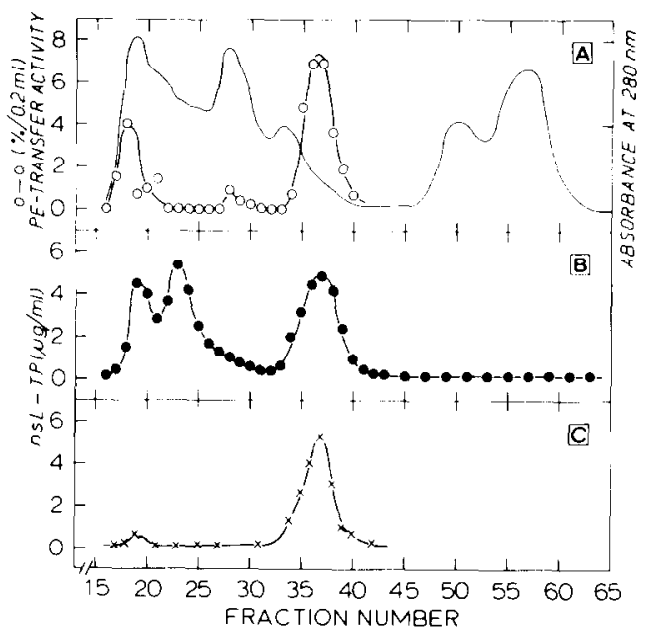

Fig. 3. Gel filtration chromatography of a $105000 \times g$ supernatant from rat liver on a column of AcA-54. $200 \mathrm{mg}$ of supernatant protein were applied. The column $(2.2 \times 100 \mathrm{~cm})$ was eluted with $0.02 \mathrm{M}$ sodium phosphate/0.01 M 2mercaptoethanol $(\mathrm{pH} \mathrm{7.2)}$ at a flow rate of $20 \mathrm{ml} / \mathrm{h} .7-\mathrm{ml}$ fractions were collected. A. Absorbance at 280 wn (- - ) and phosphatidylethanolamine transfer activity $(\mathrm{O}-\mathrm{O})$. B. Level of nonspecific lipid transfer protein as determined by enzyme immunoassay (- - ). As B, after heat treatment of column fractions at $90^{\circ} \mathrm{C}$ during $5 \min (x-\times)$.

tivity (Fig. 3A), and subjected to the enzyme immunoassay (Fig. 3B). A small amount of transfer activity was found near the void volume of the column, but the bulk of transfer activity eluted as a single peak at the position of the nonspecific lipid transfer protein (fractions 34-39). This peak was detected by the enzyme immunoassay (Fig. $3 B$ ). In addition, cross-reactive material was detected in the high molecular weight region. Heating $\left(5 \mathrm{~min}\right.$ at $90^{\circ} \mathrm{C}$ ) of the samples prior to assaying eliminated the contaminating peaks and had no effect on the peak of nonspecific lipid transfer protein (Fig. 3C). Treatment of the crossreactive material of high molecular weight with urea $(6 \mathrm{M})$ or sodium cholate $(0.5 \%, \mathrm{w} / \mathrm{v})$ followed by rechromatography did not yield an immunoreactive protein fraction in the molecular weight range of the nonspecific transfer protein. This shows that the immunoreactivity of the high molecular weight material is not due to loosely bound nonspecific transfer protein. In addition, the specific IgG bound completely to this cross-reactive material covalently linked to a sepharose-4B column. This strongly suggests that the specific 
IgG raised against a homogeneous protein is not monospecific. On the other hand, the cross-reactive material may be related to the transfer protein (see Discussion).

In order to obtain the correct levels of transfer protein the samples were routinely treated by heating. To ascertain that no transfer protein was lost during this heating step the following experiment was done. Accurate amounts of pure transfer protein were added to a fixed aliquot of rat liver $105000 \times g$ supernatant. Then the samples were heated and the total amount of transfer protein was determined. After correction for the transfer protein present in the $105000 \times g$ supernatant, it was found that the recovery ranged from 105 to $118 \%$. This has been confirmed by repeating the same experiment with a lung supernatant; the recovery ranged from 93 to $114 \%$.

By the aid of the enzyme immunoassay it was demonstrated that the antibody against the rat liver protein was cross-reactive with the nonspecific lipid transfer protein present in the $105000 \times g$ supernatant fractions from human, mouse and bovine liver. Therefore, this antibody can be used to quantify by enzyme immunoassay the nonspecific lipid transfer protein in these tissues. However, the need for standard curves requires that pure nonspecific lipid tranfer proteins from these sources are available. That is, one cannot a priori assume that the various nonspecific lipid transfer proteins have the same affinity for the specific IgG available and, hence, behave identically in the assay.

\section{Levels in rat tissues}

Table I shows the levels of nonspecific transfer protein in the $105000 \times \mathrm{g}$ supernatant from a number of rat tissues. Liver and mucosa have the highest levels with values of 0.78 and $0.46 \mu \mathrm{g}$ protein $/ \mathrm{mg}$ supernatant protein, respectively. Levels in the other tissues range from 0.06 to 0.13 $\mu \mathrm{g}$ protein $/ \mathrm{mg}$ supernatant protein. The value measured in liver agrees with the 1500 -fold purification needed to obtain a homogeneous protein from this source [3].

In Table II, levels of nonspecific lipid transfer protein in Morris hepatomas 7777, 7787 and 9633 . host livers and normal liver are compared. The levels in the host livers are comparable to that in
TABLE I

LEVEL OF NONSPECIFIC LIPID ITANSFER PROTIEIN IN VARIOUS RAT TISSUES

Values represent means \pm S.D. The numbers in parentheses are the numbers of samples.

\begin{tabular}{ll}
\hline Tissue & $\begin{array}{l}\text { Nonspecific lipid transfer protein } \\
\text { in } 105000 \times g \text { supernatant } \\
(\mu \mathrm{g} / \mathrm{mg} \text { protein })\end{array}$ \\
\hline Liver & $0.78 \pm 0.23(12)$ \\
Intestinal mucosa & $0.46 \pm 0.03(3)$ \\
Brain & $0.13 \pm 0.02(3)$ \\
Lung & $0.10 \pm 0.02(5)$ \\
Kidney & $0.09+0.01(2)$ \\
Spleen & $0.09 \pm 0.01(2)$ \\
Heart & $0.07 \pm 0.01(3)$ \\
Adrenals & $0.09 \pm 0.02(3)$ \\
Ovary & $0.12 \pm 0.02(3)$ \\
Testis & $0.06 \pm 0.01(5)$ \\
\hline
\end{tabular}

normal liver. In the fast-growing, poorly differentiated 7777 hepatoma the protein is almost absent (0.07 $\mu \mathrm{g}$ protein $/ \mathrm{mg}$ supernatant protein), whereas the slower-growing, well-differentiated 7787 and 9633 hepatomas contain intermediate amounts (0.30 $\mu \mathrm{g}$ protein $/ \mathrm{mg}$ supernatant protein). The low level in the 7777 hepatoma agrees with the barely detectable phosphatidylethanolamine tranfer activity in this tumour [9]. On the other

TABLE II

LEVEL OF NONSPECIFIC LIPID TRANSFER PROTEIN IN $105000 \times g$ SUPERNATANTS FROM MORRIS HEPATOMAS 7777, 7787 AND 9633, HOST LIVERS AND NORMAL LIVER

Values represent means \pm S.D. of the number of determinations in parentheses.

\begin{tabular}{ll}
\hline & $\begin{array}{l}\text { Nonspecific lipid transfer protein } \\
\text { in } 105000 \times g \text { supernatant } \\
(\mu \mathrm{g} / \mathrm{mg} \text { protein })\end{array}$ \\
\hline Normal liver & $0.78 \pm 0.23(12)$ \\
Hepatoma 7777 & $0.07 \pm 0.03(4)$ \\
$\quad$ Host & $0.86 \pm 0.03(2)$ \\
Hepatoma 7787 & $0.31 \pm 0.05(4)$ \\
$\quad$ Host & $0.83 \pm 0.06(2)$ \\
Hepatoma 9633 & $0.29 \pm 0.03(2)$ \\
Host & $0.78 \pm 0.18(2)$
\end{tabular}




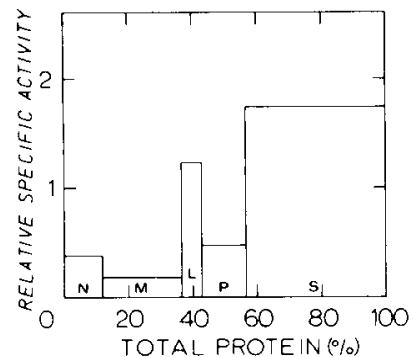

Fig. 4. Subcellular distribution of nonspecific lipid transfer protein in rat liver. On the ordinate each fraction is represented by its relative specific activity (i.e., percentage of recovered tranfer protein/percentage of total protein). On the abscissa the protein content of each fraction is expressed as percentage of total recovered protein. Fractions include nuclei and cell debris $(N)$, heavy mitochondria $(M)$, light mitochondria (L), microsomes (P) and supernatant (S).

hand, the levels in 7787 and 9633 hepatomas are 2-3-fold higher than expected on the basis of this transfer activity [9].

\section{Subcellular distribution}

The enzyme immunoassay has also been used to determine the distribution of nonspecific lipid transfer protein among the various subcellular membrane fractions. To release the transfer protein, membrane fractions were treated with sodium deoxycholate $(0.05 \%, w / v)$ prior to the assay. In Fig. 4, the subcellular distribution of transfer protein is presented according to the method of De Duve et al. [20]. This plot shows that approx. 70\% of the total nonspecific transfer protein is present in the $105000 \times g$ supernatant fraction, having the highest specific activity. The remainder of the transfer protein is distributed among the various subcellular membrane fractions. Application of the assay to total tissue homogenates indicated that the levels of nonspecific transfer protein in brain, lung, kidney, spleen, heart and adrenal were 5-10-fold lower than in liver. This agrees with the relative levels in the $105000 \times g$ supernatant fractions.

\section{Discussion}

The quantitative enzyme immunoassay described in this paper has the unique feature that it is based on the direct adsorption of the antigen to a polyvinyl surface in the presence of a large excess of bovine serum albumin. It has some resemblance to the enzyme immunoassay described by Butler [21], in which the antigen is directly adsorbed to a polystyrene surface. However, in the latter assay the total amount of protein used in the coating step must be very low (i.e., $200 \mathrm{ng}$ ) so that competition between the antigen and other proteins present for the binding sites on the polystyrene surface does not occur. In view of the low antigen (i.e., nonspecific lipid transfer protein) concentration in our samples, we used in the coating step amounts of $1-10 \mu \mathrm{g}$ of $105000 \times \mathrm{g}$ supernatant protein. In order to obtain a reproducible adsorption of the antigen to the polyvinyl surface, independent of the initial antigen concentration, we standardized the samples by addition of an excess serum albumin (i.e., $1 \mathrm{mg} \operatorname{protein} \cdot \mathrm{ml}^{-1}$ ). Although under these conditions competition between proteins for binding sites occures, the adsorption of the nonspecific lipid transfer protein is very effective: more than $30 \%$ is adsorbed during the coating step. This high extent of adsorption indicates that, compared to bovine serum albumin, the nonspecific lipid transfer protein has an extremely high affinity for the polyvinyl surface. According to the current theory, the adsorption is governed by hydrophobic interactions [22]. A wider applicability of this kind of enzyme immunoassay will depend on the adsorptive behaviour of the antigen in the presence of excess serum albumin. Preliminary experiments with the phosphatidylcholine transfer protein from rat liver have indicated that the adsoprtion of this protein is too low to allow detection (Teerlink, T., unpublished observations).

The assay developed is non-competitive, giving a linear standard curve (Fig. 2). This feature is usually seen with assays in which the antigen is bound to solid-phase antibody and subsequently measured with a second, labelled antibody [19]. This linearity improves the accuracy of the determination. Another attractive feature of the assay is that the sensitivity can be increased simply by increasing the amount of IgG used (Fig. 2). We routinely measured levels of nonspecific transfer protein in the range $0.2-2.0 \mathrm{ng}$. In addition to being sensitive the assay is simple and fast; determinations take less than $4 \mathrm{~h}$. 
After fractionation of a rat liver $105000 \times g$ supernatant on a AcA- 54 column, immunoreactive fractions were detected in the high molecular weight region (Fig. 3). At the moment, the nature of this cross-reactive material is unknown. Treatment with urea or sodium cholate did not release immunoreactive material of low molecular weight. This makes it unlikely that this material consists of nonspecific transfer protein complexed to another protein. On the other hand, it is possible that this immunoreactive material is chemically related to the transfer protein (e.g., a high molecular weight precursor). This may also explain why this material effectively adsorbs to the well in the presence of a large excess of serum albumin. However, in contrast to the nonspecific transfer protein, it cannot withstand heating at $90^{\circ} \mathrm{C}$ for $5 \mathrm{~min}$ [1]. We have made use of this heat-lability to free the samples from the cross-reactive contaminants.

In previous studies [1,9], the nonspecific lipid transfer protein was detected with a functional assay, based on the ability of the protein to transfer phosphatidylethanolamine between membranes. In principle, this transfer assay can be used to estimate levels of the nonspecific lipid transfer protein in $105000 \times g$ supernatants. On the other hand, this type of assay is rather insensitive and prone to interference by factors that may be present in the crude supernatants. This limitation does not hold for immunoassays, which are generally believed to be very specific. Therefore, we consider the enzyme immunoassay indispensable to obtain meaningful data on the levels of nonspecific lipid transfer proteins in tissues.

Table I shows that all tissues examined contain the nonspecific lipid transfer protein. The highest level is observed in liver (i.e., $0.78 \mu \mathrm{g} / \mathrm{mg}$ supernatant protein), followed by that in the intestinal mucosa $(0.46 \mu \mathrm{g} / \mathrm{mg}$ supernatant protein). It is interesting to note that when the levels of another lipid transfer protein, i.e., phosphatidylcholine transfer protein, were determined by radioimmunoassay, liver and mucosa were also found to have the highest levels [14]. All other tissues tested contain low levels of nonspecific lipid transfer protein $(0.06-0.13 \mu \mathrm{g} / \mathrm{mg}$ supernatant protein). Phosphatidylethanolamine transfer activity was not detected in $105000 \times \mathrm{g}$ supernatants from rat brain, indicating that the nonspecific transfer pro- tein was absent from this tissue [23]. In contrast, a distinct level of transfer protein was observed in the present study. Rat lung supernatants do have phosphatidylethanolamine transfer activity [24]. It was shown that the transfer activity in supernatant from type II cells was about 16-times higher than in whole lung supernatant. The relatively high level in type II cells was taken as an argument that this tranfer protein may be involved in the transfer of lung surfactant phospholipids. Our data show that the level of the nonspecific lipid transfer protein in whole lung supernatants is low. Further experiments are required to determine the level in type II cells.

Low levels were also observed in the adrenals. Recently it has been suggested that the nonspecific lipid transfer protein may be involved in the initial stages of corticosteroid biosynthesis, i.e., the formation of pregnenolone in the mitochondria [7]. In this study in vitro pregnenolone biosynthesis was enhanced by the protein transferring cholesterol from lipid droplets to the mitochondria. A cholesterol-carrying protein has been described in cytosolic preparations from adrenals, testes and ovaries [25]. This protein, however, was not fully purified and data given by the authors suggest that this protein is not identical to the nonspecific lipid transfer protein. Hence, the role of the nonspecific lipid transfer protein in the in vivo modulation of adrenal and gonadal steroidogenesis remains to be established.

It is shown in Table II that the transformation of the liver into Morris hepatomas results in a drastic reduction of the nonspecific lipid transfer protein. Particularly, the fast-growing, poorly differentiated Morris hepatoma 7777 has a very low level of this protein. It has been suggested that the nonspecific lipid transfer protein may play a role in the regulation of cholesterol metabolism $[3,11]$. If correct, its low levels in Morris hepatomas may be related to the abnormally regulated cholesterol biosynthesis in these tumours [26,27]. Moreover, the nonspecific lipid transfer protein may serve as an intracellular transport protein, transporting cholesterol in a directed way from one locus (e.g., endoplasmic reticulum, lysosomes) to another within the cell. Such a function would be in accordance with the observed high levels in liver and mucosa, tissues that are most active in cholesterol 
biosynthesis and the major sources of circulating serum cholesterol in normal animals [28]. Further studies will be needed in order to explore these and other possibilities.

\section{Acknowledgement}

This work was supported by the Koningin Wilhelmina Fonds for Cancer Research in The Netherlands.

\section{References}

1 Bloj, B. and Zilversmit, D.B. (1977) J. Biol. Chem. 252, 1613-1619

2 Bloj, B., Hughes, M.E., Wilson, D.B. and Zilversmit, D.B. (1978) FEBS Lett. 96, 87-89

3 Poorthuis, B.J.H.M., Glatz, J.F.C, Akeroyd, R. and Wirtz, K.W.A. (1981) Biochim. Biophys. Acta 665, 256-261

4 Noland, B.J., Arebalo, R.E., Hansbury, E. and Scallen, T.J. (1980) J. Biol. Chem. 255, 4282-4289

5 Trzaskos, J.M. and Gaylor, J.L. (1983) Biochim. Biophys. Acta 751, 52-65

6 Gavey, K.L., Noland, B.J. and Scallen, T.J. (1981) J. Biol. Chem. 256, 2993-2999

7 Poorthuis, B.J.H.M. and Wirtz, K.W.A. (1982) Biochim. Biophys. Acta 710, 99-105

8 Chanderbhan, R., Noland, B.J., Scallen, T.J. and Vahouny, G.V. (1982) J. Biol. Chem. 257, 8928-8934

9 Poorthuis, B.J.H.M., Van der Krift, T.P., Teerlink, T., Akeroyd, R., Hostetler, K.Y. and Wirtz, K.W.A. (1980) Biochim. Biophys. Acta 600, 376-386

10 Trzaskos, J.M. (1980) Fed. Proc. 39, 2035
11 Williams, M.T., Gaylor, J.L. and Morris, H.P. (1977) Cancer Res. 37, 1377-1383

12 Engvall, E. (1980) Methods Enzymol. 70, 419-439

13 Teerlink, T., Poorthuis, B.J.H.M., Van der Krift, T.P. and Wirtz, K.W.A. (1981) Biochim. Biophys. Acta 665, 74-80

14 Teerlink, T., Van der Krift, T.P., Post, M. and Wirtz, K.W.A. (1982) Biochim. Biophys. Acta 713, 61-67

15 Lowry, O.H., Rosebrough, N.J., Fart, A.L. and Randall, R.J. (1951) J. Biol. Chem 193, 265-275

16 Poorthuis, B.J.H.M., Op den Kamp, J.A.F. and Wirtz, K.W.A. (1982) in Techniques in Lipid and Membrane Biochemistry (Hesketh, T.R., ed.), Vol. B 414, pp. 1-16, Elsevier Biomedical Press, Amsterdam

17 Dyatlovitskaya, E.V., Timofeeva, N.G., Yakimenko, E.F., Barsukov, L.1., Muzya, G.1. and Bergelson, L.D. (1982) Eur. J. Biochem. 123, 311-315

18 Rittler, M.C. and Dempsey, M.E. (1973) Proc. Natl. Acad. Sci. USA 70, 265-269

19 Cheung, A.H., Bensadoun, A. and Cheng, C.F. (1979) Anal. Biochem. 94, 346-357

20 De Duve, C., Pressman, B.C., Gianetto, R. Wattiaux, R. and Appelmans, F. (1955) Biochem. J. 60, 604-617

21 Butler, J.E. (1981) Methods Enzymol. 73, 482-523

22 Cantarero, L.A., Butler, J.E. and Osborne, J.W. (1980) Anal. Biochem. 105, 375-382

23 Wirtz, K.W.A. (1974) Biochim. Biophys. Acta 344, 95-117

24 Post, M., Batenburg, J.J., Schuurmans, E.A.J.M. and Van Golde, L.M.G. (1980) Biochim. Biophys. Acta 620, 317-321

25 Lefevre, A., Morera, A.M. and Sacz, J.M. (1978) FEDS Lett. 89, 287-292

26 Siperstein, M.D. and Fagan, V.M. (1964) Cancer Res. 24, $1108-1115$

27 Siperstein, M.D., Fagan, V.M. and Morris, H.P. (1966) Cancer Res. 26, 7-11

28 Turley, S.D., Andersen, J.M. and Dietschy, J.M. (1981) J, Lipid Res. 22, 551-569 